\title{
Aggressiveness of Fusarium Species and Impact of Root Infection on Growth and Yield of Soybeans
}

\author{
María M. Díaz Arias, Leonor F. Leandro, and Gary P. Munkvold
}

Department of Plant Pathology and Microbiology, Iowa State University, Ames. 50011.

Accepted for publication 21 February 2013.

\begin{abstract}
Díaz Arias, M. M., Leandro, L. F., and Munkvold, G. P. 2013. Aggressiveness of Fusarium species and impact of root infection on growth and yield of soybeans. Phytopathology 103:822-832.

Fusarium spp. are commonly isolated from soybean roots but the pathogenic activity of most species is poorly documented. Aggressiveness and yield impact of nine species of Fusarium were determined on soybean in greenhouse (50 isolates) and field microplot (19 isolates) experiments. Root rot severity and shoot and root dry weights were compared at growth stages V3 or R1. Root systems were scanned and digital image analysis was conducted; yield was measured in microplots. Disease severity and root morphology impacts varied among and within species.

Fusarium graminearum was highly aggressive (root rot severity $>90 \%$ ), followed by $F$. proliferatum and $F$. virguliforme. Significant variation in damping-off (20 to $75 \%)$ and root rot severity $(<20$ to $>60 \%)$ was observed among $F$. oxysporum isolates. In artificially-infested microplots, root rot severity was low $(<25 \%)$ and mean yield was not significantly reduced. However, there were significant linear relationships between yield and root symptoms for some isolates. Root morphological characteristics were more consistent indicators of yield loss than root rot severity. This study provides the first characterization of aggressiveness and yield impact of Fusarium root rot species on soybean at different plant stages and introduces root image analysis to assess the impact of root pathogens on soybean.
\end{abstract}

Species of Fusarium are well recognized as soybean pathogens, including Fusarium oxysporum causing Fusarium wilt, F. virguliforme causing sudden death syndrome (SDS), and several species causing damping-off and Fusarium root rot $(2,16,33,36,37)$. At least 19 species of Fusarium have been isolated from soybean roots $(3,8,10,22,23,25,27,33-35,43)$. Among the species and the diseases they cause, economic impact is widely recognized for SDS and damping-off, whereas economic impacts of Fusarium wilt and root rot have not been properly documented.

Fusarium root rot is estimated to affect soybean across a geographic area covering $>1,900 \mathrm{~km}$ north to south and $1,600 \mathrm{~km}$ east to west in North America (42). Although Fusarium root rot is common and widespread, its yield impact has been difficult to quantify because the disease symptoms are not easily distinguished from other diseases and abiotic disorders. Moreover, Fusarium root rot often occurs in combination with other diseases and disorders (22).

Members of $F$. oxysporum and $F$. solani complexes are generally reported to be the major species causing root rot in soybean $(10-12,33,34)$ but additional species may be pathogenic. Previous studies on occurrence, pathogenicity, and cultivar resistance to the two predominant species complexes have been inconclusive. In 1963, French and Kennedy (14) isolated $F$. solani from soybean roots but concluded that the isolates were not pathogenic on soybean. In contrast, another study reported that $F$. solani caused root rot symptoms in soybean seedlings, reducing seedling emergence and seed yield, in greenhouse and field conditions (21). F. oxysporum is associated with the Fusarium root rot complex and can cause a range of symptoms, including damping-off, wilt, root rot, cortical decay, and vascular discoloration $(10,14,26$, 33). Pathogenicity, however, has not always been demonstrated due to significant variation among fungal strains in the complex

Corresponding author: G. P. Munkvold; E-mail address: munkvold@iastate.edu

http://dx.doi.org/10.1094/PHYTO-08-12-0207-R

(C) 2013 The American Phytopathological Society
(2,7,10-12). More recently, other species of Fusarium such as $F$. armeniacum, $F$. graminearum, $F$. proliferatum, $F$. pseudograminearum, and $F$. redolens have been reported as soybean pathogens, causing root rot on seedlings and older plants $(4,8$, 9,35,41).

Few published reports have estimated the yield impact of Fusarium root rot in soybean. In a study conducted in Delaware by Leath and Carroll (24), two soybean cultivars susceptible to Fusarium root rot incurred 47.6 and $55.6 \%$ yield loss following inoculation with $F$. oxysporum. According to Wrather et al. (39, 40), the estimated soybean yield losses to diseases caused by species of Fusarium in the United States in 1994 to 2010 were $\approx 36.2$ million bushels/year, mostly due to SDS; estimated losses due to Fusarium root rot were 6.63 million bushels/year. However, this estimate does not include the role of Fusarium spp. in seedling diseases, which caused additional losses of 34.3 million bushels/year over the same time period. Moreover, the portion of seedling disease loss that could be attributed to species of Fusarium are not agreed upon, with some reports indicating that species of Fusarium are the primary seedling pathogens, while others indicate that Pythium and Rhizoctonia spp. are the primary pathogens $(16,36)$.

In order to increase understanding of the importance of rootinfecting species of Fusarium on soybean productivity, greenhouse and field experiments were conducted in Iowa. The objectives of this study were to (i) determine aggressiveness of predominant Iowa species of Fusarium in causing soybean root rot in greenhouse conditions and (ii) estimate effects of root infection by species of Fusarium on soybean growth and yield under field conditions. In this article, "aggressiveness" refers to "relative ability to colonize and cause damage to plants" (38).

\section{MATERIALS AND METHODS}

Greenhouse and microplot field experiments were established in 2008, 2009, and 2010, at the Iowa State University (ISU) Department of Plant Pathology and Microbiology greenhouse 
facilities in Ames. Field experiments were established at two field locations near Ames, in Story County, IA.

Fusarium isolate identification. Fusarium isolates used in the study (Table 1) were obtained from soybean root samples collected during a 2007 survey of Iowa fields (7). The isolates represented the range of species recovered and the number of isolates per species reflected the frequency of isolation of the most common species (7). Isolates were recovered from soybean roots by culturing root pieces on Nash-Snyder artificial medium, which is semiselective for Fusarium spp. (31). Putative Fusarium colonies were transferred to sterile potato dextrose broth (PDB) (Difco, Benton, Dickinson and Company, Sparks, MD) in 1.5-ml centrifuge tubes and stored at $4^{\circ} \mathrm{C}$ until identified. Single-spore isolates were grown for 7 to 20 days at room temperature $(25 \pm$ $2{ }^{\circ} \mathrm{C}$ ) under fluorescent light on carnation leaf agar (CLA) modi- fied with $\mathrm{KCl}$ to favor production of more and longer microconidial chains (15 g of agar and $6 \mathrm{~g}$ of $\mathrm{KCl}$ per liter) (26) and antibiotic-amended potato dextrose agar (PDA) (streptomycin sulfate solution at $33 \mathrm{mg} \mathrm{ml}^{-1}$, neomycin sulfate solution at $40 \mathrm{mg}$ $\mathrm{ml}^{-1}$, and $39 \mathrm{~g}$ of PDA per liter of water). Each isolate was examined microscopically and identified to species following the system of Leslie and Summerell (26).

Species identity was confirmed by amplifying and sequencing the elongation factor 1- $\alpha$ gene region using primer pairs efl/ef 2 and efl/ef22, respectively (15). Cultures used for sequencing were grown on PDA at room temperature for 7 days under fluorescent light. The mycelia were harvested by scraping the culture using a sterile plastic loop and were placed into a $1.5-\mathrm{ml}$ centrifuge tube; then, each sample was freeze dried for 2 days using a lyophilizer (Freezone 6; Labconco, Kansas City, MO) (pressure of $\leq 0.133$

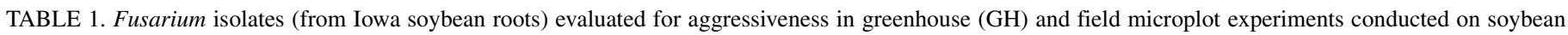
at Iowa State University (ISU) research farms between 2008 and 2010

\begin{tabular}{|c|c|c|c|c|c|c|c|c|}
\hline \multirow[b]{2}{*}{ Isolate ID } & \multirow[b]{2}{*}{ Species } & \multirow[b]{2}{*}{ Year $^{\mathrm{a}}$} & \multirow[b]{2}{*}{ County } & \multirow[b]{2}{*}{ Plant stage ${ }^{b}$} & \multirow[b]{2}{*}{ GH experiment } & \multicolumn{3}{|c|}{ Field experiments $^{\mathrm{c}}$} \\
\hline & & & & & & 1 & 2 & 3 \\
\hline FA16 & Fusarium acuminatum & 2007 & Mitchell & V3 & + & + & + & + \\
\hline FA17 & F. acuminatum & 2007 & Hardin & V3 & + & - & + & - \\
\hline FA18 & F. acuminatum & 2007 & Delaware & $\mathrm{R} 1$ & + & - & + & - \\
\hline FA19 & F. acuminatum & 2007 & Palo Alto & V4 & + & - & - & - \\
\hline FA20 & F. acuminatum & 2007 & Allamakee & V3 & + & - & - & - \\
\hline FA21 & F. acuminatum & 2007 & Hamilton & $\mathrm{R} 1$ & + & - & - & - \\
\hline FA22 & F. acuminatum & 2007 & Mitchell & V3 & + & - & - & - \\
\hline FA23 & F. acuminatum & 2007 & Cedar & $\mathrm{V} 2$ & + & - & - & - \\
\hline FE25 & F.equiseti & 2007 & O' Brien & V3 & + & - & + & + \\
\hline FE26 & F. equiseti & 2007 & Carroll & V3 & + & - & - & - \\
\hline FG1 & F. graminearum & 2007 & Butler & V3 & + & + & + & + \\
\hline FG2 & $F$. graminearum & 2007 & Butler & $\mathrm{V} 3$ & + & - & - & - \\
\hline FG3 & $F$. graminearum & 2007 & Butler & $\mathrm{V} 3$ & + & - & - & - \\
\hline FG4 & $F$. graminearum & 2007 & Floyd & $\mathrm{R} 2$ & + & - & - & - \\
\hline FG5 & $F$. graminearum & 2007 & Cedar & $\mathrm{V} 2$ & + & - & + & - \\
\hline FO36 & F. oxysporum & 2007 & Lyon & V3 & + & - & - & - \\
\hline FO37 & F. oxysporum & 2007 & Lyon & V3 & + & - & - & - \\
\hline FO38 & F. oxysporum & 2007 & Hamilton & $\mathrm{R} 1$ & + & - & + & - \\
\hline FO39 & F. oxysporum & 2007 & Lee & V3 & + & + & + & + \\
\hline FO40 & F. oxysporum & 2007 & Butler & V3 & + & - & - & - \\
\hline FO41 & F. oxysporum & 2007 & Jefferson & V3 & + & - & - & - \\
\hline FO42 & F. oxysporum & 2007 & Lee & V3 & + & - & - & - \\
\hline FO43 & F. oxysporum & 2007 & Crawford & $\mathrm{V} 2$ & + & - & + & - \\
\hline FO44 & F. oxysporum & 2007 & Winneshiek & $\mathrm{V} 2$ & + & - & - & - \\
\hline FO45 & F. oxysporum & 2007 & Lyon & V3 & + & - & - & - \\
\hline FO46 & F. oxysporum & 2007 & Crawford & $\mathrm{V} 2$ & + & - & + & - \\
\hline FO47 & F. oxysporum & 2007 & Dickinson & V3 & + & - & + & + \\
\hline FO48 & F. oxysporum & 2007 & Crawford & $\mathrm{V} 2$ & + & - & + & - \\
\hline FO49 & F. oxysporum & 2007 & Allamakee & V3 & + & - & - & - \\
\hline FP32 & F. proliferatum & 2007 & Adair & V3 & + & - & - & - \\
\hline FP33 & $F \cdot$ proliferatum & 2007 & Adair & V3 & + & - & - & - \\
\hline FP34 & $F$. proliferatum & 2007 & Audubon & V3 & + & - & - & - \\
\hline FP35 & F. proliferatum & 2007 & Benton & V3 & + & - & - & - \\
\hline FSE50 & F. semitectum & 2007 & Montgomery & V5 & + & - & - & - \\
\hline FSE51 & F. semitectum & 2007 & Montgomery & V5 & + & - & + & + \\
\hline FS6 & $F$. solani & 2007 & Louisa & V4 & + & - & + & - \\
\hline FS7 & F. solani & 2007 & Louisa & V4 & + & + & + & + \\
\hline FS8 & F. solani & 2007 & Clarke & $\mathrm{R} 1$ & + & - & + & - \\
\hline FS9 & F. solani & 2007 & Allamakee & $\mathrm{R} 2$ & + & - & + & + \\
\hline FS10 & F. solani & 2007 & Floyd & $\mathrm{V} 2$ & + & - & - & - \\
\hline FS11 & F. solani & 2007 & Floyd & $\mathrm{V} 2$ & + & - & + & - \\
\hline FS12 & F. solani & 2007 & Polk & V3 & + & - & - & - \\
\hline FS13 & F. solani & 2007 & Lyon & $\mathrm{V} 3$ & + & - & - & - \\
\hline FS14 & F. solani & 2007 & Carroll & V3 & + & - & - & - \\
\hline FS15 & F. solani & 2007 & Johnson & $\mathrm{V} 2$ & + & - & - & - \\
\hline FSP28 & F. sporotrichioides & 2007 & Calhoun & $\mathrm{V} 2$ & + & - & - & - \\
\hline FSP29 & F. sporotrichioides & 2007 & Marion & V4 & + & - & - & - \\
\hline FSP30 & F. sporotrichioides & 2007 & Lee & $\mathrm{V} 3$ & + & - & - & - \\
\hline FSP31 & F. sporotrichioides & 2007 & Calhoun & $\mathrm{V} 2$ & + & - & + & + \\
\hline FV24 & $F$. virguliforme & 2007 & Fayette & $\mathrm{V} 2$ & + & - & - & - \\
\hline
\end{tabular}

a Year collected.

${ }^{b}$ Growth stage of soybean plant at the time of collection.

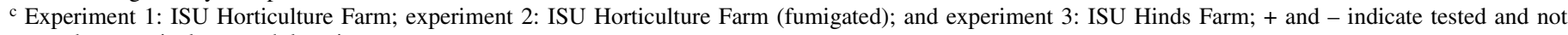
tested, respectively, at each location. 
mbar and temperature below $-40^{\circ} \mathrm{C}$ ). Immediately after lyophilization, samples were ground with a disposable pellet pestle in the tube. Genomic DNA was extracted using a modification of the cetyltrimethylammonium bromide procedure (19). During the incubation time $\left(65^{\circ} \mathrm{C}\right)$, samples were shaken every $5 \mathrm{~min}$, centrifugation conditions were at $12,000 \mathrm{rpm}$ for $10 \mathrm{~min}$, and polymerase chain reaction (PCR)-grade water was used to dissolve the DNA. DNA was quantified using a spectrophotometer and stored at $-20^{\circ} \mathrm{C}$ until processing. PCR products were sequenced at the ISU Office of Biotechnology DNA Facility. Sequences were submitted for BLAST searches for comparison with known DNA sequences in the National Center for Biotechnology Information and FUSARIUM-ID databases.

Greenhouse experiments. To compare the aggressiveness of the most common species recovered from soybean roots, $50 \mathrm{Fu}$ sarium isolates (Table 1) were used in greenhouse assays.

Each isolate was grown on PDA for 10 days at room temperature $\left(25 \pm 2^{\circ} \mathrm{C}\right)$ under $24 \mathrm{~h}$ of fluorescent lighting. Spore suspensions for inoculation were prepared by flooding cultures with $\approx 50 \mathrm{ml}$ of sterile distilled water (SDW), dislodging conidia with a disposable hockey stick, filtering through sterile cheese cloth to avoid agar residues, and adding water to obtain a final volume of $100 \mathrm{ml}$. Spores were enumerated using a hemacytometer, and the spore concentration was adjusted to $10^{6}$ conidia $\mathrm{ml}^{-1}$ by adding SDW. SDW was used as a control. Inoculum of each Fusarium isolate was prepared by adding $2 \mathrm{ml}$ of spore suspension into a bag containing previously autoclaved cornmeal-sand mixture (380 $\mathrm{ml}$ of cracked cornmeal, $1,900 \mathrm{ml}$ of sand, and $110 \mathrm{ml}$ of SDW) (30). Cornmeal-sand mixture was autoclaved twice for $45 \mathrm{~min}$ at $121.1^{\circ} \mathrm{C}$ and 16.2 to $19 \mathrm{psi}$. Inoculum was then incubated for 6 days at room temperature in the dark, and mixed every day. At planting, autoclaved sand-soil mixture (1 part soil to 2 parts sand) was mixed with fungal inoculum at a ratio (by volume) of 1 part fungal inoculum to 3 parts of sand-soil mixture. Cones of $164 \mathrm{ml}$ in volume $(3.8 \mathrm{~cm}$ in diameter and $21 \mathrm{~cm}$ in depth) were filled with the mixture. Noninoculated control plants were grown in autoclaved sand-soil amended with sterile cornmealsand mix.

Seed of soybean 'Asgrow 2403' (SDS susceptible) (Monsanto Co., St. Louis) were surface disinfested in $1 \%$ sodium hypochlorite for $2 \mathrm{~min}$ and rinsed twice for $2 \mathrm{~min}$ in SDW before planting. Three seeds were planted into the sand-soil mixture amended with fungal inoculum in cones and thinned to 1 plant per cone after emergence.

The experiment was arranged in a completely randomized design with five replicates. Each replicate consisted of a single plant per cone per isolate. Soil temperature in the greenhouse experiments was maintained at $18 \pm 1^{\circ} \mathrm{C}$ by placing cones in water baths, inside buckets filled with sand. Greenhouse air temperature was maintained at $23 \pm 5^{\circ} \mathrm{C}$. Natural light was supplemented with high-pressure sodium grow lights $(400 \mathrm{~W})$ set for a photoperiod of $14 \mathrm{~h} \mathrm{light} \mathrm{day}{ }^{-1}$. Plants were watered daily with $\approx 100 \mathrm{ml}$ of tap water. The experiment was conducted four times.

At soybean growth stage V3, plants were removed from cones and the roots were washed under a stream of tap water. Root rot severity was assessed using a visual scale as the percentage ( 0 to $100 \%$ ) of root area with brown or black discoloration. Percentage of seedling mortality due to damping-off was also documented. Mortality (\%) was evaluated as the total number of dead seedlings divided by total number of sampling units (total number of plants). After each root was evaluated for disease severity, roots were scanned using a flatbed scanner (Epson Perfection V700 Photo Scanner) and image analysis was conducted with the software WinRhizo 2008 (Regent Instruments Inc., Quebec, QC, Canada) in order to determine the effect of Fusarium isolates on root growth and root system structure. Image analysis provided estimates of root length, surface area, root volume, root diameter, and number of root tips, crossings, and forks of the root system for each individual plant. Fusarium isolates were reisolated from symptomatic root tissue of inoculated plants in order to confirm infection resulting from the inoculated species. Fungi were isolated from roots by excising two $1-\mathrm{cm}$-long root pieces from each plant. Root pieces were surface disinfected in $0.5 \% \mathrm{NaOCl}$ for $2 \mathrm{~min}$, rinsed three times in SDW, and blotted dry; then, root pieces were embedded in antibiotic-amended PDA medium and incubated at room temperature $\left(25 \pm 2{ }^{\circ} \mathrm{C}\right)$ for 7 days under fluorescent light. Numbers of root pieces with respective $\mathrm{Fu}$ sarium isolate were recorded for each sample. Shoot and root dry weights were measured for each plant after oven drying at $80^{\circ} \mathrm{C}$ for $24 \mathrm{~h}$.

Microplot field experiments. Microplot experiments were established at the ISU research farms in Story County, IA, in 2008 to 2010. Three experiments were conducted at two locations to estimate the effects of root infection by species of Fusarium on soybean growth and yield in the field (Table 1).

Inoculum was prepared using the protocol described by Hartman et al. (17) for infestation of white sorghum grains with Fusarium spp. Sorghum grain was washed in tap water and then $750 \mathrm{ml}$ of sorghum grain was placed in 1-liter mason jars and autoclaved for $60 \mathrm{~min}$ at $121^{\circ} \mathrm{C}$ on two consecutive days. Each jar was inoculated with 12 4-mm-diameter plugs of 10-day-old cultures of a single Fusarium isolate grown on PDA for 5 days. Jars were then shaken every day and incubated under constant fluorescent light at room temperature $\left(25 \pm 2{ }^{\circ} \mathrm{C}\right)$ for 3 weeks. The colonized sorghum grain was dried under a laminar flow hood for 1 to 2 days, then weighed and stored in bags at $4^{\circ} \mathrm{C}$ for 2 weeks. To infest soil, a trench was dug in each microplot; length of the trench depended on each microplot length. Inoculum was placed $7.5 \mathrm{~cm}$ deep, mixed with field soil by hand throughout the plot, and then covered with the remaining soil. Each plot was infested with $350 \mathrm{~g}$ of colonized sorghum grain at the Horticulture Farm and $1,000 \mathrm{~g}$ on plots at the Hinds Farm; inoculum amounts were dependent on plot size and number of rows per plot.

Experiment 1: Horticulture farm, nonfumigated. The study was conducted in 2008 to 2010 at the ISU Horticulture Farm located near Gilbert, IA (Story County). The experiment was established at a site maintained with grass for at least 20 years in order to reduce the likelihood of naturally occurring soybean-infecting species of Fusarium. The field was moldboard plowed and disked before planting. The experiment was planted on 13 June 2008, 14 May 2009, and 18 May 2010. Microplots consisted of rectangular (0.762-by- $0.483 \mathrm{~m}$ ) plots containing a single row of 20 soybean plants planted at $3.81 \mathrm{~cm}$ apart of '92M02' (Pioneer Hi-Bred International, Inc., Des Moines, IA) in 2008 and Asgrow 2403 in 2009 and 2010. Soybean seed were treated with Rhizobium (Rhizo-Stick, Becker Underwood Inc., Ames, IA) to stimulate nodulation in all three experiments. Five replicate plots per isolate were established. In total, four isolates representing the most frequent species of Fusarium ( $F$. acuminatum, F. graminearum, $F$. oxysporum, and $F$. solani), were included (7), and there was a noninoculated control. Plots were infested annually with the same Fusarium isolate. At growth stage R1, a subsample of four soybean plants was removed from each microplot to evaluate root rot severity and root and shoot dry weight, as described above. Plants were removed at the end of the row of each microplot. In addition, one extra plant was collected from each plot in each experiment to reisolate species of Fusarium previously inoculated in soil. Four symptomatic root pieces from these plants, two from the tap root and two from lateral roots, were used in order to confirm infection by the appropriate isolate. Fungi were isolated using the same procedure previously described for greenhouse experiments, with the modification that roots were first cultured on Nash-Snyder and then on PDA in order to confirm infection by the appropriate isolate.

The effects of Fusarium isolates on root growth and structure were evaluated using image analysis by WinRhizo software in the 
2009 and 2010 trials. At harvest, yield (grams per plot), seed moisture content (percent), and seed size (number of seed per kilogram) were measured.

Seed yield was obtained by hand harvesting plants at maturity by cutting the stems at the soil line. Mature plant roots were left in the ground to maintain crop residues that could favor fungi survival for the next year. A small-plot combine was used to thresh soybean samples and obtain seed weight per plot. Final yield was adjusted to $13 \%$ moisture. Seed size was calculated using the total weight of seed harvested per plot and the total weight of a subsample of 100 seeds.

Experiment 2: Horticulture farm, fumigated. A second experiment was also conducted in 2008 to 2010 at the ISU Horticulture Farm located near Gilbert, IA (Story County). The study was established in a turf site with no history of soybean planting, adjacent to experiment 1 . Prior to planting in 2008, the field was moldboard plowed and disked and, on 28 May, the soil in the entire experimental area was fumigated with Vapam HL (42\% of sodium methyldithiocarbamate [metam sodium at $0.51 \mathrm{~kg} / \mathrm{liter}$ ), applied at a rate of $358 \mathrm{~kg}$ a.i. $\mathrm{ha}^{-1}$ by using a series of drip tubing covered with plastic tarps (the hot gas method) across the target area, in order to reduce the existing Fusarium population in the soil (although soil populations were not measured before or after fumigation). In 2009 and 2010, soil was not fumigated in order to avoid planting delays.

Microplots consisted of rectangular (0.762-by-0.483-m) plots containing a single row of soybean plants of Pioneer cultivar 92M02 in 2008 and Asgrow 2403 in 2009 and 2010. The experiment was planted on 13 June, 14 May, and 18 May, in 2008, 2009, and 2010, respectively. Nineteen Fusarium isolates from seven species of Fusarium (F. acuminatum, F. equiseti, $F$. graminearum, $F$. oxysporum, $F$. semitectum, $F$. solani, and $F$. sporotrichioides) and a noninoculated control treatment were tested. Each plot was infested with the same Fusarium isolate every year. Plots were inoculated following the same procedure described in experiment 1. Experimental design, number of replicate plots per isolate, number of seed planted, number of plants sampled, and disease and yield assessments were the same as in experiment 1 .

Experiment 3: Hinds Farm. The experiment was conducted in 2009 and 2010 at the ISU Hinds Research Farm near Ames (Story County). The study was established in a site with no history of soybean planting for at least 5 years; the previous crop was a forage grass mixture. The experiment was planted on 22 May 2009 and 20 May 2010. Nine Fusarium isolates from seven species of Fusarium ( $F$. acuminatum, F. equiseti, F. graminearum, $F$. oxysporum, $F$. semitectum, $F$. solani, and $F$. sporotrichioides) and a noninoculated control were used. Every year, the soil in each 1-by-1-m plot was infested with the same isolate in the same location, and two rows, $19.1 \mathrm{~cm}$ apart, of 56 soybean plants per plot (Asgrow 2403) were planted. Inoculation was the same as described previously in experiments 1 and 2 . Ten replicate plots per isolate were established. At growth stage R1, a subsample of 10 soybean plants ( 5 per row) was removed from the end of each row. Root rot, root growth, and yield were assessed as described above.

Average air temperature, soil temperature, and precipitation from May to July were recorded for each year of the experiments. Data were obtained from the Iowa Environmental Mesonet, Department of Agronomy, ISU (http://mesonet.agron.iastate.edu/ climodat/).

Data analysis. For greenhouse experiments, the normal and homogeneous distribution of residuals was examined using SAS PROC PLOT. Analysis of variance was conducted using PROC GLIMMIX in SAS (version 9.2; SAS Institute, Cary, NC). Differences among species averaged over isolates were estimated using the Tukey-Kramer test. Differences among isolates were tested separately for each species; means from inoculated treatments (isolates) were compared against the noninoculated treat- ment using Dunnett's $t$ test and among each other using the Tukey-Kramer test. Treatments (species and isolates) were considered significantly different if $P \leq 0.05$. SAS PROC CORR was used to calculate linear correlation coefficients among phenotypic variables. Correlation analysis was performed on combined data from the four trials together. For the three field experiments, treatments were assigned to plots in a randomized complete block design. Each experiment was analyzed separately. The normal and homogeneous distribution of residuals was examined using SAS PROC PLOT. The 2 or 3 years of measurements were treated as repeated observations on the same plots and analyzed using SAS PROC GLIMMIX with a normal distribution. A preliminary analysis was conducted using the treatment-year interaction as a fixed effect. When this interaction was not significant, the treatment main effects were compared, averaging data for the 3 years of experiments 1 and 2 and 2 years of experiment 3 . Pairwise differences among treatment means were compared using the TukeyKramer test and considered significantly different if $P \leq 0.05$. In addition, Dunnett's $t$ test was used to compare means from inoculated treatments against the noninoculated treatment.

For each field experiment, simple linear regression analysis was performed separately for each Fusarium isolate to measure the linear association that best predicted the yield loss associated with root rot severity and root morphological characteristics. SAS PROC CORR was used to calculate linear correlation coefficients among phenotypic variables. Correlation analysis was performed separately for each experiment.

\section{RESULTS}

Greenhouse experiments. In the greenhouse experiments, the nine Fusarium spp. differed significantly in their aggressiveness on soybean (Fig. 1). Root rot severity differed among species, with $F$. graminearum causing the most severe root rot, followed by $F$. virguliforme, $F$. proliferatum, $F$. sporotrichioides, and $F$. solani. Mean root rot severity caused by $F$. oxysporum and $F$. equiseti did not differ significantly from the noninoculated control (root rot severity does not take into account damping-off symptoms). However, all species, with the exception of $F$. semitectum, caused significant detrimental effects on root dry weight $(P=$ $0.0001)$, shoot dry weight $(P<0.0001)$, and root morphological characteristics $(P=0.002$ to $P<0.0001)$ compared with the control (Fig. 1).

Among individual isolates, significant variation in aggressiveness occurred for all root variables measured $(P \leq 0.05)$ (Fig. 2). F. graminearum isolate FG5 was the most aggressive isolate, causing $96 \%$ root rot severity and significant detrimental effects on all root morphological characteristics, followed by $F$. virguliforme FV24 (Fig. 2). Significant variation in aggressiveness was also observed among isolates within $F$. acuminatum, $F$. equiseti, F. oxysporum, F. semitectum, and F. solani (Table 2). Among the $14 F$. oxysporum isolates tested, only one isolate differed significantly in root rot severity from the noninoculated control (Fig. 2). However, detrimental effects on root development characteristics were observed for all $F$. oxysporum isolates. Significant reductions were observed in root and shoot dry weight, total root length, root surface area, total root volume, and in the number of tips, crossings, and forks when plants were inoculated with $F$. oxysporum isolates compared with the noninoculated plants. Similar results were also observed with the $F$. acuminatum isolates. Reductions in total root length and total root surface were more consistent indicators of aggressiveness than root rot severity (Fig. 2). In general, mean root diameter was not significantly affected by Fusarium infection except for isolates $F$. graminearum FG5 and $F$. virguliforme FV24; mean root diameter for plants affected by these isolates was significantly greater (fewer small-diameter roots) than for noninoculated controls (Table 2). Each species was reisolated from inoculated, symptomatic plants, 
thus offering proof of pathogenicity by compliance with Koch's postulates.

Seedling growth measurements (shoot and root weights) were positively correlated $(P<0.0001)$ with all of the root morphological characteristics measured in the root image analysis, except mean root diameter, which had a significant negative correlation with shoot and root weights. Conversely, root rot severity had significant negative correlations with shoot and root weights, though the correlations were weaker than those between shoot and root weights and the root morphology variables. Root rot severity was also negatively correlated with all of the root morphological characteristics, except mean root diameter, with which there was a significant positive correlation. Additionally, there were significant positive correlations among all of the root morphological characteristics, with the exception of mean root diameter, which was negatively correlated with all the other root morphological characteristics (Table 3).

Seedling mortality was observed in all experimental runs for several of the isolates tested. F. oxysporum isolates caused the most severe damping-off symptoms, followed by $F$. proliferatum. Isolates such as $F$. oxysporum $\mathrm{FO} 45$ and $F$. proliferatum FP35 killed, on average, 75 and $70 \%$ of the plants, respectively (Fig. 3),

Microplot field experiments. During this study, average temperatures in 2008 for May to July were 15.6 to $23.3^{\circ} \mathrm{C}$, precipitation was 215.7 to $234.2 \mathrm{~mm}$, and soil temperature was 14.4 to $24.1^{\circ} \mathrm{C}$. For 2009 , air temperature and precipitation ranges were 15.6 to $20.6^{\circ} \mathrm{C}$ and 102.1 to $69.9 \mathrm{~mm}$, respectively, and soil temperature was 16.3 to $24.4^{\circ} \mathrm{C}$. In 2010 , average air temperatures in May to July were 16.7 to $23.9^{\circ} \mathrm{C}$, precipitation was 92.5 to $173.0 \mathrm{~mm}$, and soil temperatures were 17.7 to $26.8^{\circ} \mathrm{C}$.

Experiment 1. Treatment-year interactions were not significant $(P>0.05)$ for disease severity, root dry weight, yield, root volume, and diameter; therefore, treatment effects were tested for all years combined but interactions were significant $(P \leq 0.05)$ for root growth characteristics, such as total root length, surface area, and number of tips, forks, and crossings; therefore, data from each year were analyzed separately.

Fusarium isolates differed significantly in their ability to cause root rot in the field. Analysis of variance indicated significant differences among isolates $(P=0.023)$ in root rot severity but root rot severity was significantly higher only for $F$. oxysporum isolate FO39 and F. graminearum isolate FG1 compared with the noninoculated control treatment. Inoculation with Fusarium isolates did not significantly affect shoot dry weight or root dry weight. No differences in mean yield $(0.72 \mathrm{~kg} / \mathrm{plot})$ or seed size (1,950 seeds) were found among isolates. However, differences in root morphological characteristics were observed. Fusarium inoculation affected root surface area, length, and number of tips, crossings, and forks, although the effects varied among years. The same species of Fusarium used for inoculation were recovered 80 to $90 \%$ of the time from symptomatic root pieces of an arbitrarily selected plant from each plot; the remaining 10 to $20 \%$ consisted of other Fusarium spp., Trichoderma spp., and Penicillium spp.

Experiment 2. Treatment-year interactions were not significant for all variables; therefore, treatment effects were tested for all
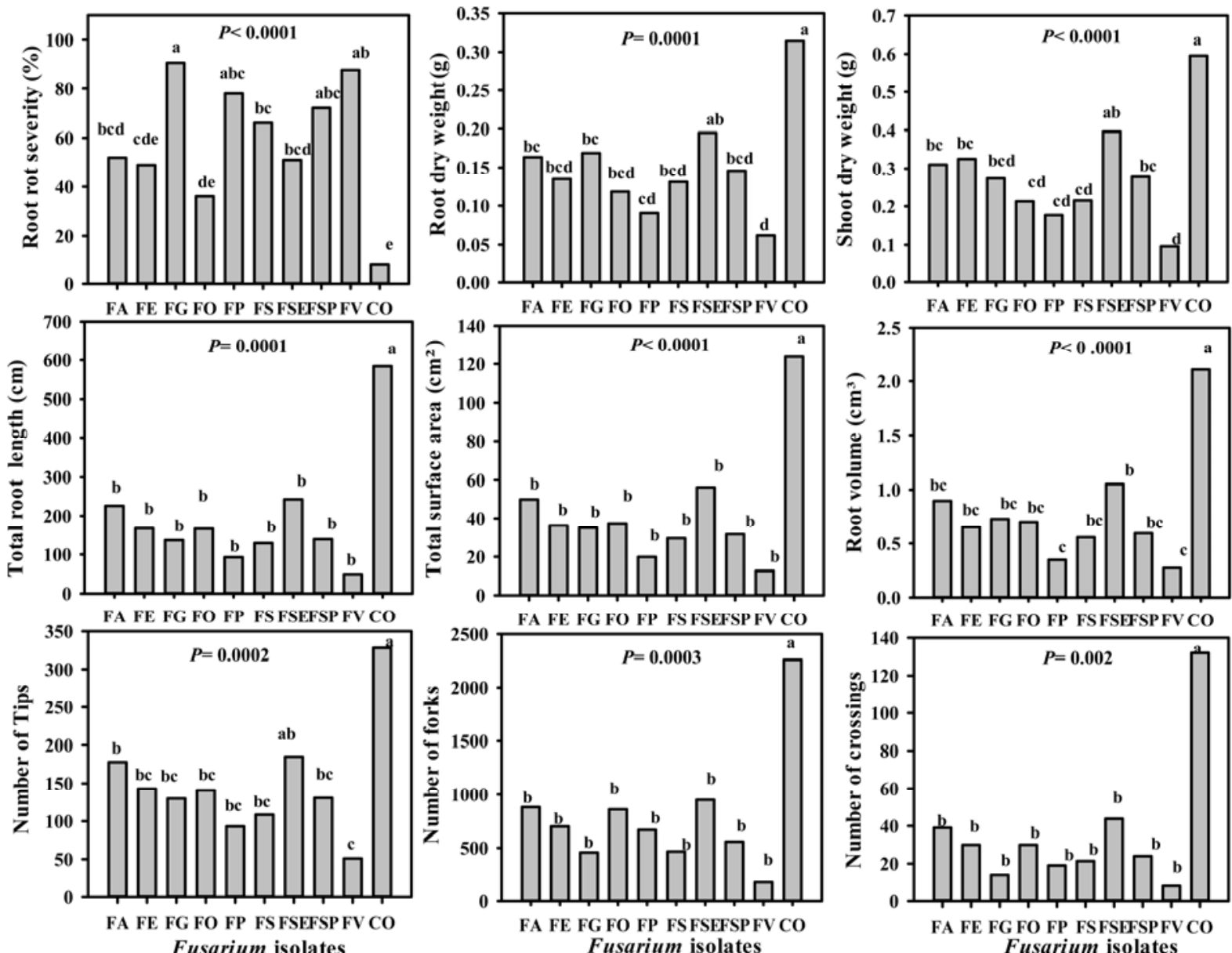

Fig. 1. Effects of Fusarium spp. on root rot severity (\%), shoot and root dry weight (g), total root length (cm), surface area $\left(\mathrm{cm}^{2}\right)$, root diameter $(\mathrm{mm})$, total root volume $\left(\mathrm{cm}^{3}\right)$, and number of tips, forks, and crossings on soybean roots under greenhouse conditions. $\mathrm{FA}=$ Fusarium acuminatum, $\mathrm{FE}=$ F. equiseti, $\mathrm{FG}=$ $F$. graminearum, $\mathrm{FO}=F$. oxysporum, $\mathrm{FP}=F$. proliferatum, $\mathrm{FS}=F$. solani, $\mathrm{FSE}=F$. semitectum, $\mathrm{FSP}=F$. sporotrichioides, $\mathrm{FV}=F$. virguliforme, and $\mathrm{CO}=$ noninoculated control. Least-square means with the same letter are not significantly different $(P=0.05)$. Data presented are means of four experimental trials. 
years combined. Significant differences in root rot severity $(P<$ $0.034)$, root dry weight $(P<0.023)$, root length $P<0.0002)$, surface area $(P<0.004)$, root volume $(P<0.045)$, and number of tips $(P<0.001)$, forks $(P<0.001)$, and crossings $(P<0.001)$ were found among treatments (data not shown). Isolations made from arbitrarily selected plants resulted in $100 \%$ recovery of the same Fusarium spp. used for inoculation of the plots in 2008 and 80 to $95 \%$ recovery in 2009 and 2010 , respectively. No differences in mean yield $(0.91 \mathrm{~kg} / \mathrm{plot})$ or seed size $(1,830$ seeds $)$ were found among isolates.

Experiment 3. Treatment-year interactions were not significant for root rot severity, root and shoot dry weight, root length, and number of tips but interactions were significant for all other root growth characteristics measured; therefore, treatment effects were tested separately within each year. Inoculation with Fusarium isolates had an effect on root rot severity $(P<0.036)$ but Dunnett's $t$ test showed that increases in root rot severity occurred only for roots infested with $F$. solani FS7 and $F$. equiseti FE25 compared with the noninoculated control (Fig. 4A). Root length differed among treatments, but a significant reduction was only observed for $F$. solani FS9, F. oxysporum FO39 and F. sporotrichioides FSP31, compared with the noninoculated control (Fig. 4B). Significant effects were observed in the number of tips for isolates $F$. sporotrichioides FSP31, F. solani FS9, and F. semitectum FSE51 (Fig. 4C). No difference in mean yield was observed among isolates (Fig. 4D). Fusarium inoculation also affected root surface area, root diameter, and number of crossings and forks depending of the year sampled. For example, isolate effects were not significant for root surface area when the 2 years were combined. However, in 2010 alone, plants infested with isolates FS9, FO39, FO47, FG1, FSE51, and FSP31 showed detrimental effects on root surface area when compared with the noninoculated control. The species used for inoculation were recovered from 60 to $70 \%$ of the sampled root pieces. No significant treatment effects were found for seed size, seed moisture, and shoot and root dry weight in the 2 years of the experiment.

Regression and correlation results Although mean yields per plot and seed size did not differ significantly among Fusarium isolates, significant linear relationships were found between root characteristics (root rot severity, dry weight, and root structure) and yield for some of the Fusarium isolates (Fig. 5). In experiment 1 , regression analysis conducted for $F$. graminearum isolate FG1 showed that the relationship between root severity and yield $\left(R^{2}=0.667, P=0.208\right)$ was not significant but there was a significant positive relationship between mean root diameter $\left(R^{2}=\right.$ $0.960, P=0.003$ ) and yield (Fig. 5C). No significant relationships were found between yield and other variables measured for the rest of the isolates tested.

In experiment 2 , significant relationships were found for several isolates between root rot severity and root development characteristics with yield. $F$. acuminatum FA18 showed the strongest relationship between root rot and yield loss (Fig. 5B), followed by F. solani FS7 (Fig. 5E), F. oxysporum FO43, F. graminearum FG5, and $F$. sporotrichioides FSP31, all of which showed significant negative relationships between root rot and yield; the coefficient of determination $\left(R^{2}\right)$ for these relationships was 0.658 to 0.932 . Other Fusarium isolates did not show significant relationships between root rot severity and yield but other root characteristics were better yield predictors. For example, F. solani FS11 showed a strong positive relationship between total root length and yield $\left(R^{2}=0.937\right)$ (Fig. $\left.5 \mathrm{~F}\right)$. The same result was observed for $F$. acuminatum FA18 and F. oxysporum FO39 in terms

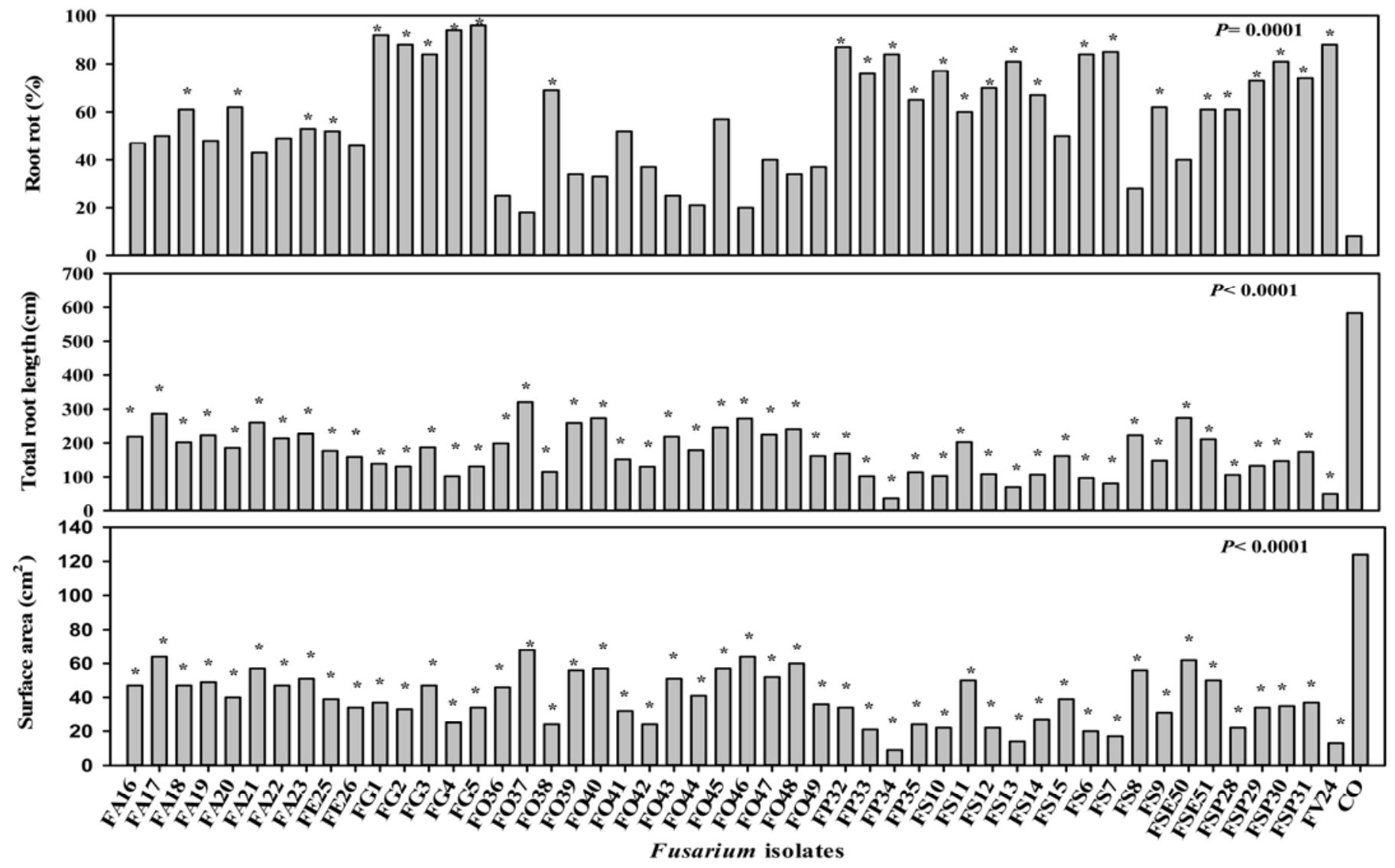

Fig. 2. Effects of Fusarium isolates on root rot severity $(\%)$, total root length $(\mathrm{cm})$, and total surface area $\left(\mathrm{cm}^{2}\right)$, on soybean roots at V3 stage under greenhouse conditions. $\mathrm{FA}=$ Fusarium acuminatum, $\mathrm{FE}=F$. equiseti, $\mathrm{FG}=F$. graminearum, $\mathrm{FO}=F$. oxysporum, $\mathrm{FP}=F$. proliferatum, $\mathrm{FS}=F$. solani, $\mathrm{FSE}=F$. semitectum, $\mathrm{FSP}=F$. sporotrichioides, $\mathrm{FV}=F$. virguliforme, and $\mathrm{CO}=$ noninoculated control; $*$ indicates significantly different from the noninoculated control treatment at $P=0.05$ level using Dunnett's $t$ test. Data presented are means of four experimental trials. 
of root surface area and root dry weight, respectively (Fig. 5A and D, respectively). In addition, isolates such as $F$. oxysporum FO38 and $F$. graminearum FG5 showed significant relationships between all root morphological characteristics and yield, except with diameter.

In experiment 3, significant relationships between yield and root rot severity, number of tips, and root surface area were observed for 4 of the 10 Fusarium isolates tested. F. equiseti FE25 isolate showed a significant negative relationship between root rot severity and yield $\left(R^{2}=0.494, P=0.023\right)$. In addition, isolates F. solani FS7 $(P=0.009)$ and F. graminearum FG1 $(P=0.024)$ demonstrated significant relationships between number of tips and yield $\left(R^{2}=0.643\right.$ and 0.542 , respectively). Furthermore, isolate $F$. oxysporum FO39 showed a significant relationship between root surface area and yield $\left(R^{2}=0.427, P=0.040\right)$. No significant relationships were found between yield and other variables measured for other isolates tested.
Linear correlation analyses did not reveal consistent significant correlations between yield and the other variables measured. Results differed among years and locations.

\section{DISCUSSION}

In this study, nine Fusarium spp. were shown to cause root rot symptoms on soybean during both vegetative and reproductive plant stages in greenhouse and field conditions. Infection by all Fusarium spp. resulted in root rot or physical changes in root morphological characteristics, with significant variation among and within species. Furthermore, significant linear relationships between yield and root health indicators indicated the potential for some Fusarium isolates to cause yield reductions.

Greenhouse data on the soybean cultivar tested (Asgrow 2403) provided new information on the relative aggressiveness of species of Fusarium during early vegetative growth stages. Root

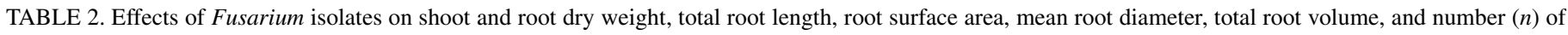
tips, forks, and crossings on roots of soybean seedlings grown in an infested sand-soil mixture under greenhouse conditions ${ }^{\text {a }}$

\begin{tabular}{|c|c|c|c|c|c|c|c|c|c|c|}
\hline $\begin{array}{l}\text { Isolate } \\
\text { ID }\end{array}$ & Species & $\begin{array}{l}\text { Shoot dry } \\
\text { weight (g) }\end{array}$ & $\begin{array}{c}\text { Root dry } \\
\text { weight }(\mathrm{g})\end{array}$ & $\begin{array}{l}\text { Length } \\
(\mathrm{cm})\end{array}$ & $\begin{array}{c}\text { Surface } \\
\text { area }\left(\mathrm{cm}^{2}\right)\end{array}$ & $\begin{array}{l}\text { Diameter } \\
(\mathrm{mm})\end{array}$ & $\begin{array}{l}\text { Volume } \\
\left(\mathrm{cm}^{3}\right)\end{array}$ & $\begin{array}{l}\text { Tips } \\
(n)\end{array}$ & $\begin{array}{l}\text { Forks } \\
(n)\end{array}$ & $\begin{array}{c}\text { Crossings } \\
(n)\end{array}$ \\
\hline FA16 & Fusarium acuminatum & $0.32 *$ & $0.14 *$ & $219.1 *$ & $46.9 *$ & 0.67 & $0.81 *$ & $176^{*}$ & $753 *$ & $37 *$ \\
\hline FA17 & F. acuminatum & 0.40 & 0.21 & $287.2 *$ & $63.6^{*}$ & 0.73 & $1.14 *$ & 216 & $1,069^{*}$ & $50 *$ \\
\hline FA18 & F. acuminatum & $0.30 *$ & $0.16^{*}$ & $202.1 *$ & $47.3 *$ & 0.76 & $0.90 *$ & $152 *$ & $790 *$ & $32 *$ \\
\hline FA19 & F. acuminatum & $0.29 *$ & $0.15 *$ & $215.6^{*}$ & $47.6^{*}$ & 0.79 & $0.86 *$ & $162 *$ & $856^{*}$ & $40 *$ \\
\hline FA20 & F. acuminatum & $0.26^{*}$ & $0.13 *$ & $189.0 *$ & $40.4^{*}$ & 0.73 & $0.69 *$ & $153^{*}$ & $740 *$ & $32 *$ \\
\hline FA21 & F. acuminatum & $0.33^{*}$ & $0.17 *$ & $261.2 *$ & $56.5^{*}$ & 0.71 & $1.00 *$ & 209 & $1,123^{*}$ & $48^{*}$ \\
\hline FA22 & F. acuminatum & $0.28 *$ & $0.16^{*}$ & $211.1 *$ & $46.5^{*}$ & 0.71 & $0.83 *$ & $181^{*}$ & $834 *$ & $37 *$ \\
\hline FA23 & F. acuminatum & $0.31 *$ & $0.18 *$ & $226.8 *$ & $50.9 *$ & 0.75 & $0.94 *$ & $175^{*}$ & $894 *$ & $41 *$ \\
\hline FE25 & F. equiseti & $0.33^{*}$ & $0.14 *$ & $176.8^{*}$ & $39.2 *$ & 0.76 & $0.71 *$ & $152 *$ & $748 *$ & $33 *$ \\
\hline FE26 & $F$. equiseti & $0.33 *$ & $0.13 *$ & $155.0 *$ & $33.6^{*}$ & 0.72 & $0.60 *$ & $134^{*}$ & $652 *$ & $28 *$ \\
\hline FG1 & F. graminearum & $0.31 *$ & $0.18 *$ & $138.4^{*}$ & $36.5^{*}$ & 0.83 & $0.77 *$ & $131 *$ & $477 *$ & $11^{*}$ \\
\hline FG2 & $F$. graminearum & $0.24 *$ & $0.16^{*}$ & $131.0 *$ & $33.3 *$ & 0.85 & $0.69 *$ & $111^{*}$ & $460 *$ & $16^{*}$ \\
\hline FG3 & $F$. graminearum & $0.33 *$ & 0.20 & $185.8 *$ & $47.0^{*}$ & 0.80 & $0.95^{*}$ & $170^{*}$ & $550 *$ & $19 *$ \\
\hline FG4 & $F$. graminearum & $0.22 *$ & $0.13 *$ & $96.7 *$ & $24.1 *$ & 0.87 & $0.49 *$ & $105^{*}$ & $333^{*}$ & $10 *$ \\
\hline FG5 & F. graminearum & $0.29 *$ & $0.18 *$ & $130.2^{*}$ & $34.1 *$ & $0.89 *$ & $0.73 *$ & $132 *$ & $452 *$ & $16^{*}$ \\
\hline FO36 & F. oxysporum & $0.20 *$ & $0.12 *$ & $161.5^{*}$ & $37.9 *$ & 0.75 & $0.73 *$ & $127 *$ & $591 *$ & $23 *$ \\
\hline FO37 & F. oxysporum & $0.22 *$ & $0.13 *$ & $277.4^{*}$ & $55.3^{*}$ & 0.69 & $0.93 *$ & 216 & $1,093^{*}$ & $58 *$ \\
\hline FO38 & F. oxysporum & $0.22 *$ & $0.09 *$ & $87.4 *$ & $19.0^{*}$ & 0.69 & $0.35^{*}$ & $107^{*}$ & $358 *$ & $19 *$ \\
\hline FO39 & F. oxysporum & $0.24 *$ & $0.15^{*}$ & $227.8 *$ & $50.1 *$ & 0.79 & $0.91 *$ & $165^{*}$ & $1,003^{*}$ & $43^{*}$ \\
\hline FO40 & F. oxysporum & $0.27 *$ & $0.12 *$ & $237.6^{*}$ & $50.2 *$ & 0.68 & $0.86^{*}$ & 199 & $903 *$ & $47 *$ \\
\hline FO41 & F. oxysporum & $0.15^{*}$ & $0.10 *$ & $149.0 *$ & $31.2 *$ & 0.76 & $0.53 *$ & $130 *$ & $543 *$ & $24 *$ \\
\hline FO42 & F. oxysporum & $0.16^{*}$ & $0.05 *$ & $95.8 *$ & $17.2^{*}$ & 0.69 & $0.26^{*}$ & $113^{*}$ & $418^{*}$ & $31 *$ \\
\hline FO43 & F. oxysporum & $0.21 *$ & $0.11 *$ & $171.7 *$ & $40.6^{*}$ & 0.84 & $0.78 *$ & $130^{*}$ & $680^{*}$ & $26^{*}$ \\
\hline FO44 & F. oxysporum & $0.21 *$ & $0.12 *$ & $172.2^{*}$ & $39.7 *$ & 0.78 & $0.74 *$ & $136^{*}$ & $757 *$ & $31 *$ \\
\hline FO45 & F. oxysporum & $0.26^{*}$ & $0.14 *$ & $193.2 *$ & $45.5^{*}$ & 0.78 & $0.87 *$ & 161 & $791 *$ & $26^{*}$ \\
\hline FO46 & F. oxysporum & $0.23 *$ & $0.15^{*}$ & $215.9 *$ & $52.9 *$ & 0.81 & $1.07 *$ & 198 & $815^{*}$ & $31 *$ \\
\hline FO47 & F. oxysporum & $0.28 *$ & $0.15^{*}$ & $222.5^{*}$ & $50.8^{*}$ & 0.78 & $0.94 *$ & $163^{*}$ & $915^{*}$ & $33 *$ \\
\hline FO48 & F. oxysporum & $0.27 *$ & $0.17 *$ & $210.6^{*}$ & $51.4^{*}$ & 0.83 & $1.04 *$ & $156^{*}$ & $890 *$ & $33 *$ \\
\hline FO49 & F. oxysporum & $0.26^{*}$ & $0.11 *$ & $147.6^{*}$ & $33.5^{*}$ & 0.73 & $0.61 *$ & $129 *$ & $575^{*}$ & $27 *$ \\
\hline FP32 & F. proliferatum & $0.24 *$ & $0.12 *$ & $143.4^{*}$ & $28.9^{*}$ & 0.69 & $0.48 *$ & $136^{*}$ & $659 *$ & $32 *$ \\
\hline FP33 & $F$. proliferatum & $0.18^{*}$ & $0.10^{*}$ & $93.8 *$ & $19.9 *$ & 0.79 & $0.35 *$ & $102 *$ & $401 *$ & $20 *$ \\
\hline FP34 & F. proliferatum & $0.12 *$ & $0.05 *$ & $25.0 *$ & $6.4^{*}$ & 0.80 & $0.13^{*}$ & $37 *$ & $113 *$ & $5 *$ \\
\hline FP35 & F. proliferatum & $0.17 *$ & $0.08 *$ & $111.6^{*}$ & $22.6^{*}$ & 0.79 & $0.38 *$ & $104 *$ & $458 *$ & $25^{*}$ \\
\hline FS10 & F. solani & $0.16^{*}$ & $0.09 *$ & $103.1 *$ & $22.2 *$ & 0.69 & $0.39 *$ & $106^{*}$ & $351 *$ & $17 *$ \\
\hline FS11 & F. solani & $0.36^{*}$ & 0.20 & $202.7 *$ & $49.7 *$ & 0.81 & $0.98 *$ & $146^{*}$ & $763^{*}$ & $29 *$ \\
\hline FS12 & F. solani & $0.18^{*}$ & $0.09 *$ & $108.3^{*}$ & $22.2^{*}$ & 0.69 & $0.37 *$ & $108^{*}$ & $340 *$ & $22 *$ \\
\hline FS13 & F. solani & $0.11 *$ & $0.09 *$ & $68.0 *$ & $13.4 *$ & 0.75 & $0.22 *$ & $69 *$ & $245^{*}$ & $15^{*}$ \\
\hline FS14 & F. solani & $0.21 *$ & $0.15^{*}$ & $106.7 *$ & $27.5^{*}$ & 0.83 & $0.58 *$ & $93 *$ & $425^{*}$ & $14 *$ \\
\hline FS15 & F. solani & $0.24 *$ & 0.20 & $160.3^{*}$ & $38.6^{*}$ & 0.76 & $0.75^{*}$ & $124 *$ & $582 *$ & $23 *$ \\
\hline FS6 & F. solani & $0.17 *$ & $0.08 *$ & $93.0 *$ & $19.0^{*}$ & 0.71 & $0.31 *$ & $94 *$ & $361 *$ & $17 *$ \\
\hline FS7 & F. solani & $0.16^{*}$ & $0.08 *$ & $79.5^{*}$ & $16.9^{*}$ & 0.84 & $0.30 *$ & $74 *$ & $242 *$ & $15^{*}$ \\
\hline FS8 & F. solani & $0.38 *$ & 0.20 & $223.6^{*}$ & $56.0^{*}$ & 0.82 & $1.15^{*}$ & $136^{*}$ & $714^{*}$ & $31 *$ \\
\hline FS9 & F. solani & $0.22 *$ & $0.12 *$ & $144.6^{*}$ & $30.5^{*}$ & 0.71 & $0.52 *$ & $125^{*}$ & $629 *$ & $28 *$ \\
\hline FSE50 & F. semitectum & 0.44 & 0.21 & $274.6^{*}$ & $61.9 *$ & 0.77 & $1.14 *$ & 216 & $1,132 *$ & $56^{*}$ \\
\hline FSE51 & F. semitectum & $0.35^{*}$ & $0.18 *$ & $211.4^{*}$ & $50.4^{*}$ & 0.78 & $0.97 *$ & $154^{*}$ & $768 *$ & $32 *$ \\
\hline FSP28 & F. sporotrichioides & $0.22 *$ & $0.10 *$ & $106.2^{*}$ & $22.4^{*}$ & 0.72 & $0.39 *$ & $115^{*}$ & $421 *$ & $22 *$ \\
\hline FSP29 & F. sporotrichioides & $0.30 *$ & $0.18 *$ & $131.4^{*}$ & $33.2 *$ & 0.80 & $0.68 *$ & $117^{*}$ & $500 *$ & $18 *$ \\
\hline FSP30 & F. sporotrichioides & $0.32 *$ & $0.16^{*}$ & $146.7 *$ & $34.9 *$ & 0.85 & $0.68 *$ & $131^{*}$ & $580 *$ & $23 *$ \\
\hline FSP31 & F. sporotrichioides & $0.27 *$ & $0.14 *$ & $174.0^{*}$ & $36.6^{*}$ & 0.69 & $0.62 *$ & $160^{*}$ & $732 *$ & $34 *$ \\
\hline FV24 & $F$. virguliforme & $0.10^{*}$ & $0.06^{*}$ & $49.7 *$ & $12.7 *$ & $0.95 *$ & $0.27 *$ & $51 *$ & $177 *$ & $8 *$ \\
\hline Control & None & 0.60 & 0.31 & 580.4 & 123.0 & 0.69 & 2.09 & 327 & 2,242 & 131 \\
\hline
\end{tabular}

a Seeds that failed to emerge were excluded; * indicates significantly different from the noninoculated control treatment at $P=0.05$ level using Dunnett's $t$ test. 
rot severity differed among species of Fusarium and isolates, with $F$. graminearum isolates causing the most severe root rot symptoms, followed by isolates of $F$. virguliforme, $F$. proliferatum, $F$. sporotrichioides, and $F$. solani. Severe root rot observed in plants inoculated with $F$. graminearum and $F$. virguliforme agrees with previous studies that also demonstrated pathogenicity of these two Fusarium spp. on soybean $(5,35,37,41)$. However, the emergence of $F$. graminearum as an important soybean root pathogen is relatively recent. In 1976, Nyvall (34) reported that $F$. roseum (an obsolete species that included $F$. graminearum) was commonly isolated from aboveground parts of soybean plants but very rarely from the roots. Similarly, in a survey conducted during the late 1980s, Leslie et al. (25) reported on the isolation of several species of Fusarium from corn, sorghum, and soybean fields but did not isolate $F$. graminearum from soybean or soybean fields. More recent studies $(5,35,41)$ have established this species as an important root rot pathogen on soybean. In our study, both $F$. graminearum and $F$. virguliforme infected soybean roots, causing a light brown to black discoloration and a reduction in root and shoot mass, total root length, volume, and numbers of tips and forks. In addition, these species caused an increase in average root diameter, as a result of fewer small-diameter roots in the complete root system. Infection by other Fusarium spp. also caused detrimental changes on root morphological characteristics, particularly in total root length and surface area. The negative effects resulted in poor plant development that could have been caused by reduction in physical support, nodulation, and absorption and movement of water and nutrients from the soil to the entire plant, as has been previously suggested $(1,6,16)$.

Significant variation in aggressiveness was observed among F. oxysporum isolates, some of which caused severe damping off. Other isolates caused root rot, whereas yet others caused little or

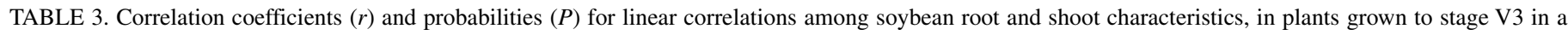
sand-soil mixture infested with various species of Fusarium ${ }^{\mathrm{a}}$

\begin{tabular}{|c|c|c|c|c|c|c|c|c|c|}
\hline Variable & $\begin{array}{c}\text { Shoot dry } \\
\text { weight }\end{array}$ & $\begin{array}{l}\text { Root dry } \\
\text { weight }\end{array}$ & $\begin{array}{l}\text { Root } \\
\text { length }\end{array}$ & $\begin{array}{c}\text { Root surface } \\
\text { area }\end{array}$ & $\begin{array}{c}\text { Mean root } \\
\text { diameter }\end{array}$ & $\begin{array}{c}\text { Root } \\
\text { volume }\end{array}$ & $\begin{array}{l}\text { Tips } \\
(n)\end{array}$ & $\begin{array}{l}\text { Forks } \\
(n)\end{array}$ & $\begin{array}{c}\text { Crossings } \\
(n)\end{array}$ \\
\hline Root rot $(r)$ & -0.27244 & -0.24904 & -0.51286 & -0.51341 & 0.21223 & -0.4858 & -0.44085 & -0.49555 & -0.43272 \\
\hline$P$ & $<0.0001$ & $<0.0001$ & $<0.0001$ & $<0.0001$ & $<0.0001$ & $<0.0001$ & $<0.0001$ & $<0.0001$ & $<0.0001$ \\
\hline Shoot dry weight $(r)$ & $\ldots$ & 0.7133 & 0.71967 & 0.76726 & -0.11124 & 0.77483 & 0.64414 & 0.6965 & 0.56646 \\
\hline$P$ & $\ldots$ & $<0.0001$ & $<0.0001$ & $<0.0001$ & 0.0017 & $<0.0001$ & $<0.0001$ & $<0.0001$ & $<0.0001$ \\
\hline Root dry weight $(r)$ & $\ldots$ & $\ldots$ & 0.72526 & 0.78564 & -0.08106 & 0.80863 & 0.68019 & 0.68112 & 0.55703 \\
\hline$P$ & $\ldots$ & $\ldots$ & $<0.0001$ & $<0.0001$ & 0.0214 & $<0.0001$ & $<0.0001$ & $<0.0001$ & $<0.0001$ \\
\hline Root length $(r)$ & $\ldots$ & $\ldots$ & $\ldots$ & 0.97563 & -0.33427 & 0.89255 & 0.92511 & 0.95661 & 0.90151 \\
\hline$P$ & $\ldots$ & $\ldots$ & $\ldots$ & $<0.0001$ & $<0.0001$ & $<0.0001$ & $<0.0001$ & $<0.0001$ & $<0.0001$ \\
\hline Root surface area $(r)$ & $\ldots$ & $\ldots$ & $\ldots$ & $\ldots$ & -0.20987 & 0.96909 & 0.87767 & 0.93697 & 0.81163 \\
\hline$P$ & $\ldots$ & $\ldots$ & $\ldots$ & $\ldots$ & $<0.0001$ & $<0.0001$ & $<0.0001$ & $<0.0001$ & $<0.0001$ \\
\hline Mean root diameter $(r)$ & $\ldots$ & $\ldots$ & $\ldots$ & $\ldots$ & $\ldots$ & -0.05036 & -0.42551 & -0.29473 & -0.42634 \\
\hline$P$ & $\ldots$ & $\ldots$ & $\ldots$ & $\ldots$ & $\ldots$ & 0.1524 & $<0.0001$ & $<0.0001$ & $<0.0001$ \\
\hline Root volume $(r)$ & $\ldots$ & $\ldots$ & $\ldots$ & $\ldots$ & $\ldots$ & $\ldots$ & 0.77497 & 0.86212 & 0.67068 \\
\hline$P$ & $\ldots$ & $\ldots$ & $\ldots$ & $\ldots$ & $\ldots$ & $\ldots$ & $<0.0001$ & $<0.0001$ & $<0.0001$ \\
\hline Tips $(n)(r)$ & $\ldots$ & $\ldots$ & $\ldots$ & $\ldots$ & $\ldots$ & $\ldots$ & $\ldots$ & 0.88343 & 0.84387 \\
\hline$P$ & $\ldots$ & $\ldots$ & $\ldots$ & $\ldots$ & $\ldots$ & $\ldots$ & $\ldots$ & $<0.0001$ & $<0.0001$ \\
\hline Forks $(n)(r)$ & $\ldots$ & $\ldots$ & $\ldots$ & $\ldots$ & $\ldots$ & $\ldots$ & $\ldots$ & $\ldots$ & 0.89793 \\
\hline$P$ & $\ldots$ & $\ldots$ & $\ldots$ & $\ldots$ & $\ldots$ & $\ldots$ & $\ldots$ & $\ldots$ & $<0.0001$ \\
\hline
\end{tabular}

a Data combined for four greenhouse experiments; $n=$ number.

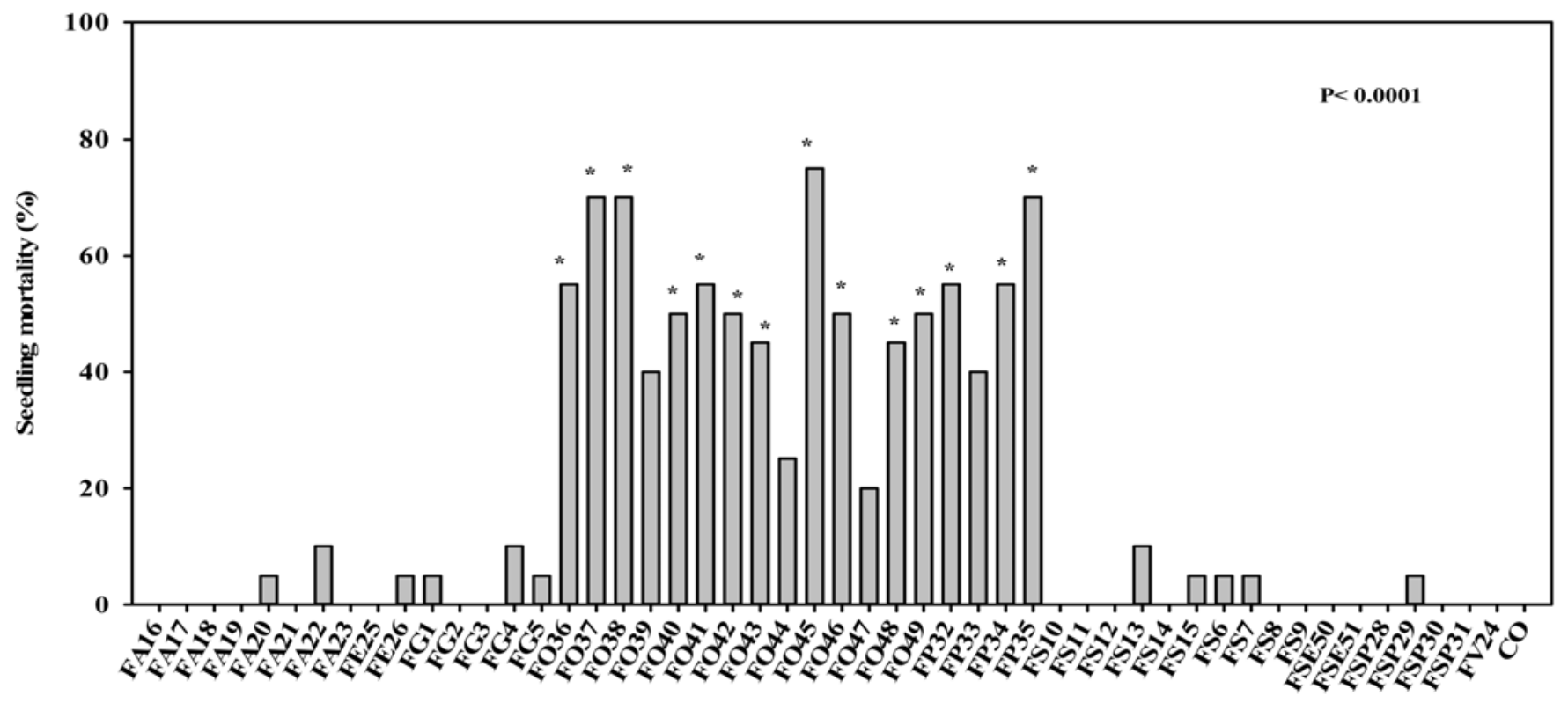

Fusarium isolate

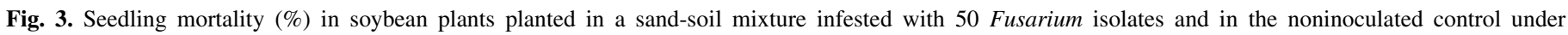

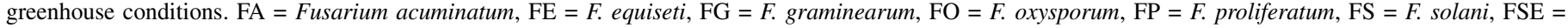

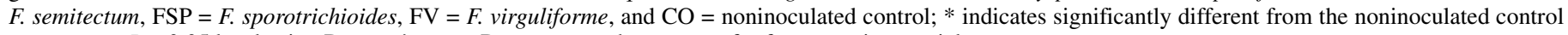
treatment at $P=0.05$ level using Dunnett's $t$ test. Data presented are means for four experiment trials. 
no disease symptoms compared with the noninoculated controls. This result was similar to that of Farias and Griffin (10), who found that only $41 \%$ of $F$. oxysporum isolates from soybean roots were able to cause root rot symptoms following inoculation. Variation among $F$. oxysporum isolates is partially due to the occurrence of multiple species within this complex (26). In this study, isolates designated as $F$. oxysporum included all members of the species complex, including some isolates of $F$. commune (M. E. Ellis, M. M. Diaz Arias, D. R. Cruz Jimenez, G. P. Munkvold, and L. F. Leandro, unpublished data). In contrast to $F$. oxysporum, $F$. solani caused little or no damping off in this study. F. oxysporum and $F$. solani are widely reported as the most frequently isolated species on soybean roots, hypocotyl, and cotyledon tissues of seedlings $(11,14,15,20,21)$. The high incidence of damping-off in this study is consistent with work by Farias and Griffin (11), who reported that $F$. oxysporum was primarily isolated from diseased cotyledons and $F$. solani from roots of seedlings grown in naturally infested soil under greenhouse conditions. These observations would indicate that $F$. oxysporum may be more important as a pathogen on cotyledons, and F. solani more important as a root pathogen. In contrast, Nyvall

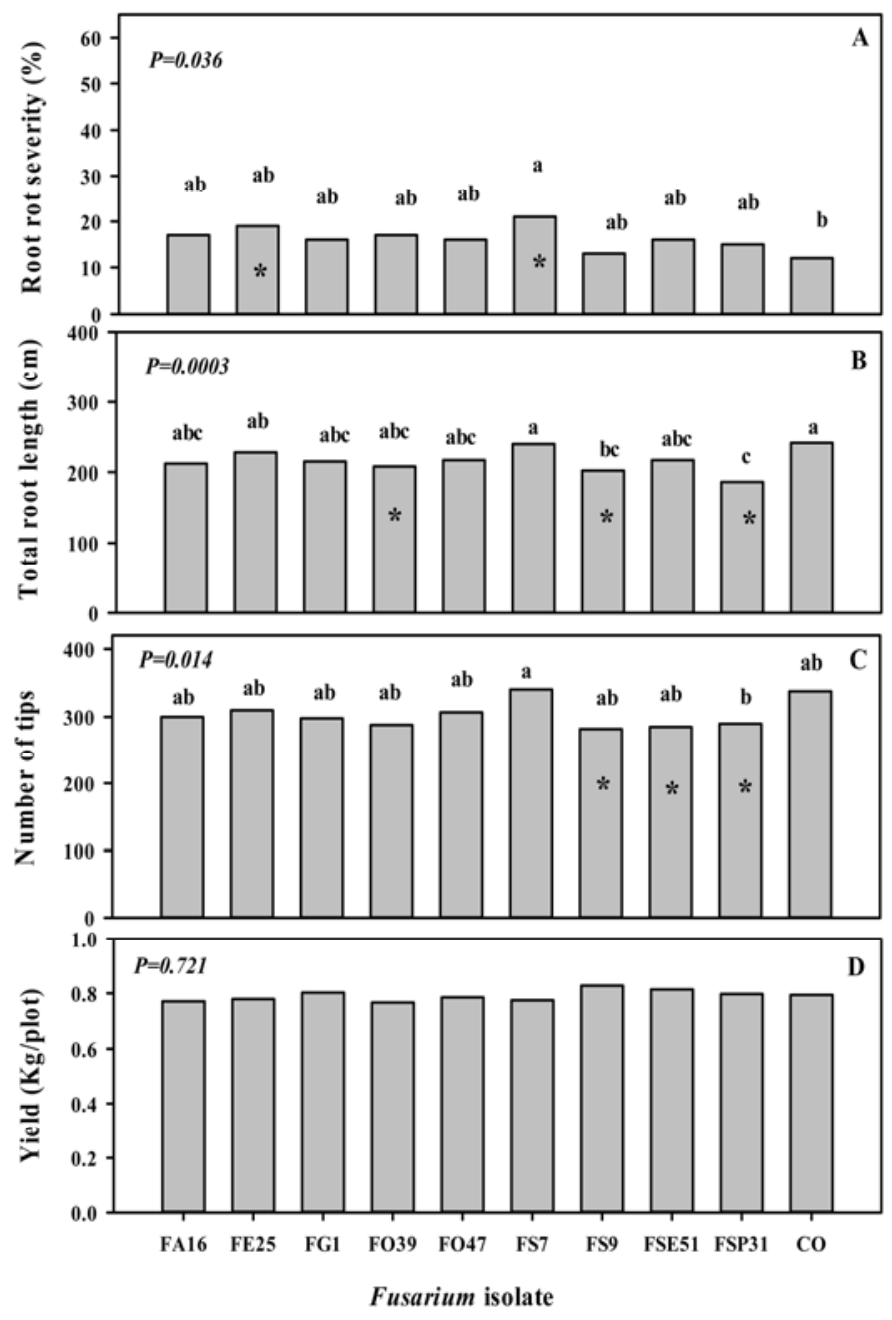

Fig. 4. Effects of 10 Fusarium isolates on root morphological characteristics on soybean plants grown in microplot conditions in experiment 3, at the Iowa State University Hinds Farm, Ames. Data shown are means from 2009 and 2010. A, Root rot severity (\%); B, total root length (cm); C, number of tips; D, yield. Least-square means with the same letter are not significantly different $(P=0.05) . \mathrm{FA}=$ Fusarium acuminatum, $\mathrm{FE}=F$. equiset, $\mathrm{FG}=F$. grami nearum, $\mathrm{FO}=F$. oxysporum, $\mathrm{FS}=F$. solani, $\mathrm{FSE}=F$. semitectum, $\mathrm{FSP}=$ $F$. sporotrichioides, and $\mathrm{CO}=$ noninoculated control; $*$ indicates significant different from the noninoculated control treatment at $P=0.05$ level using Dunnett's $t$ test.
(34) found that $F$. solani was rarely isolated from soybean roots in Iowa, whereas $F$. oxysporum was the most common Fusarium sp. isolated from both roots and stems.

F. oxysporum also is a well-known saprophyte of soybean plant tissues (34), and it can colonize plant roots without causing symptoms (11). In fact, some strains of $F$. oxysporum are used as effective biocontrol agents against pathogenic $F$. oxysporum strains and other root pathogens $(13,28)$. These biocontrol strains colonize roots and discourage pathogenic infections through competitive displacement or by inducing systemic resistance in the host (13). The various roles attributed to $F$. oxysporum (pathogen, saprophyte, symbiont, and biocontrol agent) are likely a reflection of the diverse collection of genotypes that comprise this species complex. Further work is needed to develop methods to more precisely characterize and distinguish among genotypes and phenotypes within the $F$. oxysporum complex.

Damping-off was also observed on plants inoculated with $F$. proliferatum. Isolates of this species produced high seedling mortality, suggesting the potential importance of $F$. proliferatum as another soybean seedling pathogen in Iowa. In maize, F. proliferatum is well known as part of the fungal complex causing seedling diseases and stalk and ear rots later in the growing season $(29,30)$. For soybean, the species was recently reported as a new root rot pathogen after isolates were identified from a soybean root survey conducted in Iowa in 2007 (7), and their pathogenicity to soybean roots was shown in greenhouse conditions (8). Results from the survey work and those from this study confirmed that $F$. proliferatum has a wide host range that now also includes soybean.

Our results showing that $F$. graminearum and $F$. proliferatum were aggressive soybean root rot pathogens suggest that maize crop residue could be an important source of inoculum for soybean root rot, and that maize-soybean rotation may promote the disease. Soybean producers in Iowa use reduced-tillage or notillage practices to preserve soil structure, increase organic matter, and prevent erosion. However, these crop cultural practices may favor survival of Fusarium spp. on crop residues on the soil surface, which may affect both soybean and maize plants (25).

Several Fusarium isolates were less aggressive in field experiments compared with greenhouse conditions. Low root rot severity observed in the field may have been due to unfavorable environmental conditions for root rot. Our results regarding yield impacts of Fusarium inoculation contrast with work by Leath and Carroll (24), who demonstrated yield losses of 48 and $56 \%$ in field trials in two different locations after inoculation with $F$. oxysporum. The differences between the two studies may have resulted from varying environmental conditions. The cool, wet weather pattern early in the 2008 season might have favored disease development and increased root rot severity; however, delayed planting in 2008 did not expose plants to these favorable conditions. In contrast, in 2009 and 2010, above-normal soil temperatures and low moisture levels probably did not favor severe Fusarium root rot that may have caused a significant effect on yield loss. Although the precise combinations of environmental conditions favoring Fusarium root rot on soybean are not known, it has been reported that the disease is more severe under cool, wet conditions (34). Studies on the epidemiology of Fusarium root rot on soybean are needed to better interpret the results of these studies.

Nevertheless, the significant negative relationships between yield and root rot severity and root morphological characteristics, obtained from regression analysis of individual isolates, provided evidence for potential yield losses due to infection by some $F u$ sarium spp. In addition, within a species, some Fusarium isolates may cause yield loss as a result of root rot while others may cause visual root rot symptoms without affecting yield, possibly because they cause only superficial root rot. Lack of correlation in some cases between root rot and yield may be due to the inability 
of visual root rot assessments to distinguish between superficial or cortical decay and decay occurring deeper in the root tissue that may damage the vascular system. For some Fusarium spp., it has been shown that yield loss occurs only if the fungus colonizes the root vascular tissue (32). In this study, some of the most aggressive isolates tested in the greenhouse, such as F. graminearum FG1 and FG5, F. acuminatum FA18, F. sporotrichioides FSP31, and F. solani FS7, also showed strong relationships between root variables and yield loss observed in field conditions. These isolates have potential detrimental effects on soybean productivity under favorable field conditions. More research is required to determine environmental effects on the aggressiveness of individual Fusarium spp. and their interactions with each other and the host. Future studies should investigate the use of multiple Fusarium isolates as inoculum, as well as combinations of Fusarium and other soilborne pathogens, to determine whether these combinations induce synergistic effects on soybean roots under field conditions.

Digital image analysis is very effective for quantification of the effects of soilborne pathogens on root morphological characteristics, which could be important indicators of reduced potential uptake of water and nutrients by infected soybean roots $(1,18)$. Therefore, measurement of root morphological characteristics using WinRhizo software may be more sensitive than visual root rot assessments for measuring root damage and possible yield impact of root infection by Fusarium spp. Many isolates that did not show high root rot severity in the field did, however, cause detrimental effects on root morphology. Correlation analysis in this study indicated that seedling growth was highly correlated with root morphological characteristics measured by image analysis at growth stage V3. Mean root diameter was negatively correlated with the other variables, probably because higher mean root diameter is associated with a loss of fine roots and a poorly developed or degraded root system characterized by few, large roots. These greenhouse results did not correspond to consistently significant correlations between yield and these same root characteristics in the field. In this study, it was observed that the relationships between these root variables and yield is variable. The complexity of interactions between soybean plants and environmental stresses under field conditions makes it difficult to predict the effect of individual factors such as soil pathogens on yield. Correlating yield with root morphology can be complicated by issues such as determination of the most appropriate time for root sampling, incomplete root extraction from field soil, and other factors affecting plant-to-plant yield differences. A more thorough field study would be needed in order to establish relationships between season-long root growth and yield.

This research has provided information on species of Fusarium that can be aggressive pathogens with potential for causing soybean yield loss, and has contributed to a better understanding of the importance of the disease in Iowa. Additional research, however, is required to quantify environmental conditions and biotic and abiotic components that could be conducive to damage caused by Fusarium root rot in soybean fields.

\section{F. acuminatum (FA18)}

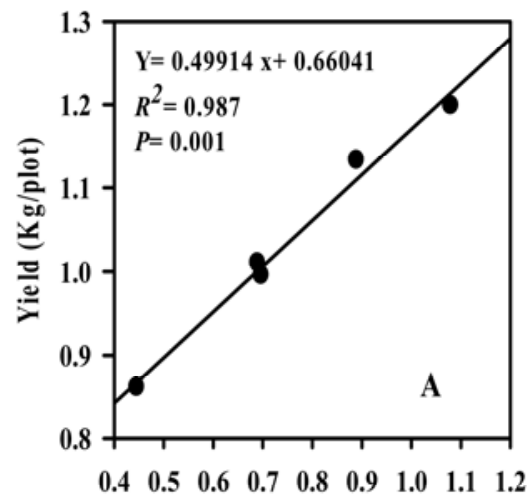

Root dry weight (g)

F. oxysporum (F039)

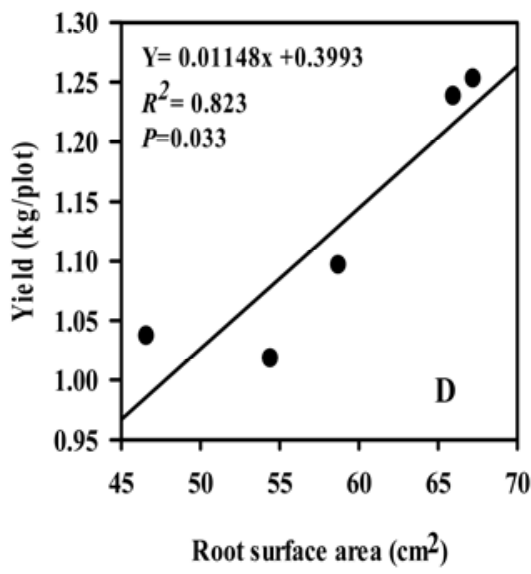

F. acuminatum (FA18)

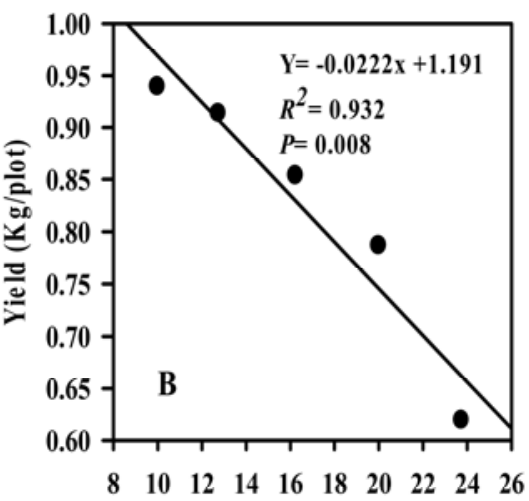

Disease severity (\%)

F. solani (FS7)

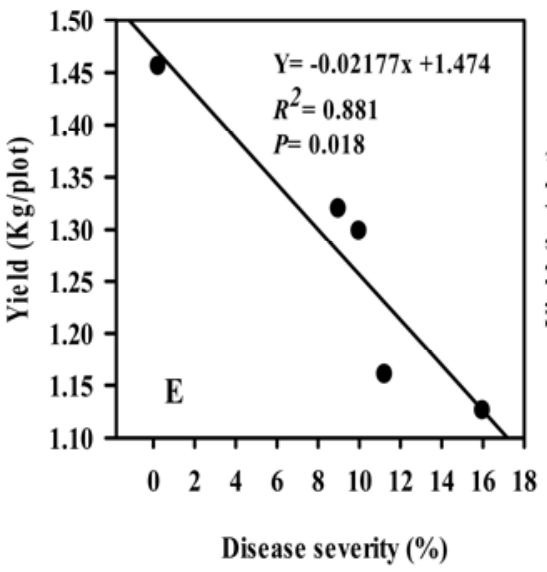

F. graminearum (FG1)

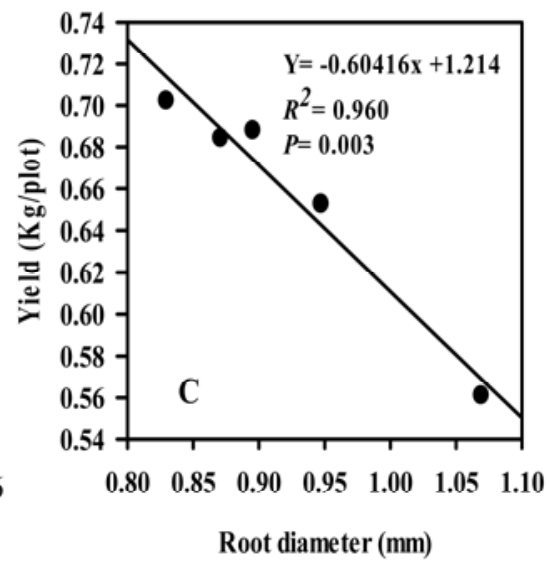

F. solani (FS11)

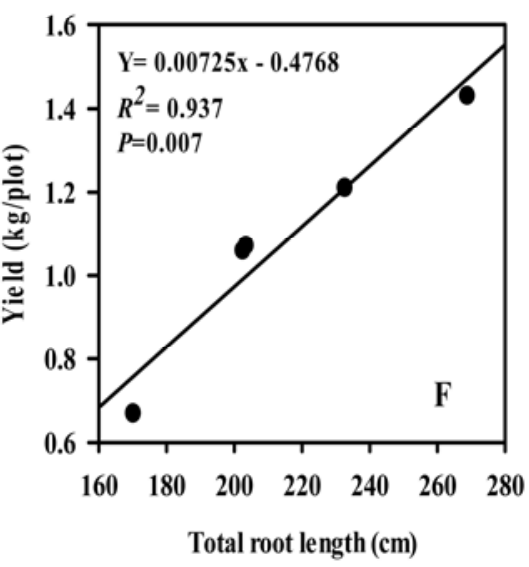

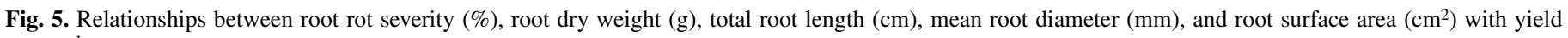

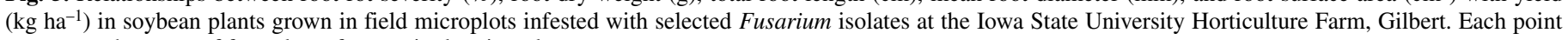
represents the mean of four plants from a single microplot. 


\section{ACKNOWLEDGMENTS}

This project was funded by the Iowa Soybean Association and United States Department of Agriculture North Central Integrated Pest Management grant program. We thank N. Howell and the staff of the ISU Horticulture Farm for their help with field trials; D. Volkers for assistance with greenhouse experiments; M. Beattie, M. Agudelo, A. Algreen, and A. Gutierrez for their technical assistance and cooperation in this study; G. Tylka and S. Cianzio for providing helpful suggestions for revising the manuscript; and P. Dixon, ISU Department of Statistics, for his assistance with data analysis.

\section{LITERATURE CITED}

1. Aiken, R. M., and Smucker, A. J. M. 1996. Root system regulation of whole plant growth. Annu. Rev. Phytopathol. 34:325-346.

2. Armstrong, G. M., and Armstrong, J. K. 1950. Biological races of the Fusarium causing wilt of cowpeas and soybeans. Phytopathology 40:181193.

3. Bienapf1, J. C. 2011. Fusarium and Phytophthora species associated with root rot of soybean (Glycinemax). Ph.D. thesis, the University of Minnesota, Minneapolis.

4. Bienapfl, J. C., Malvick, D. K., and Percich, J. A. 2010. First Report of Fusarium redolens causing root rot of soybean in Minnesota. Plant Dis. 94:1069.

5. Broders, K. D., Lipps, P. E., Paul, P. A., and Dorrance, A. E. 2007. Evaluation of Fusarium graminearum associated with corn and soybean seed and seedling disease in Ohio. Plant Dis. 91:1155-1160.

6. Cichy, K. A., and Snapp, S. S. 2007. Fusarium root rot incidence and root system architecture in grafted common bean lines. Plant Soil 300:233244.

7. Díaz Arias, M. M. 2012. Fusarium species infecting soybean roots: frequency, aggressiveness, yield impact and interaction with the soybean cyst nematode. Ph.D. thesis, Iowa State University, Ames.

8. Díaz Arias, M. M., Munkvold, G., and Leandro. L. 2011. First report of Fusarium proliferatum causing root rot on soybean (Glycine max) in the United States. Plant Dis. 95:1316.

9. Ellis, M. L., Díaz Arias, M. M., Leandro, L. F., and Munkvold, G. P. 2012. First report of Fusarium armeniacum causing seed root on soybean (Glycine max) in the United States. Plant Dis. 96:1693.

10. Farias, G. M., and Griffin, G. J. 1989. Roles of Fusarium oxysporum and Fusarium solani in Essex disease of soybean in Virginia. Plant Dis. 73:3842.

11. Farias, G. M., and Griffin, G. J. 1990. Extent and pattern of early soybean seedling colonization by Fusarium oxysporum and F. solani in naturally infested soil. Plant Soil 123:59-65.

12. Ferrant, N. P., and Carroll, R. B. 1981. Fusarium wilt of soybean in Delaware. Plant Dis. 65:596-599.

13. Fravel, D., Olivain, C., and Alabouvette, C. 2003. Fusarium oxysporum and its biocontrol. New Phytol. 157:493-502. Online publication. doi:10.1046/j.1469-8137.2003.00700.x

14. French, E. R., and Kennedy, W. B. 1963. The role of Fusarium in the root rot complex of soybean in Minnesota. Plant Dis. Rep. 47:672-676.

15. Geiser, D. M., Jimenez-Gasco, M. M., Kang, S., Makalowska, I., Veeraraghavan, N., Ward, T. J., Zhang, N., Kuldau, G. A., and O'Donnell, K. 2004. FUSARIUM-ID v. 1.0: A DNA sequence database for identifying Fusarium. Eur. J. Plant Pathol. 110:473-479.

16. Grant, C. E., Phipps, P. M., and Roane, C. W. 1981. Etiology of a damping off disease of soybeans in Virginia. (Abstr.) Phytopathology 71:767.

17. Hartman, G. L., Huang, Y. H., Nelson, R. L., and Noel, G. R. 1997. Germplasm evaluation of Glycine max for resistance to Fusarium solani, the causal organism of sudden death syndrome. Plant Dis. 81:515-518.

18. Himmelbauer, M. L., Loiskandl, W., and Kastanek, F. 2004. Estimating length, average diameter and surface area of fine roots using two different image analyses systems. Plant Soil 260:111-120.

19. Innis, M. A., Gelfand, D. H., Sninsky, J. J., and White, T. J. 1990. PCR Protocols: A Guide to Methods and Applications. Academic Press Inc., New York.

20. Killebrew, J. F., Roy, K. W., and Abney, T. S. 1993. Fusaria and other fungi on soybean seedlings and roots of older plants and interrelationships among fungi, symptoms, and soil characteristics. Can. J. Plant. Pathol. $15: 139-146$.

21. Killebrew, J. F., Roy, K. W., Lawrence, G. W., McLean, K. S., and Hodges, H. H. 1988. Greenhouse and field evaluation of Fusarium solani pathogenicity to soybean seedlings. Plant Dis. 72:1067-1070.

22. Klag, N. G., Papavizas, G. C., Bean, G. A., and Kantzes, J. G. 1978. Root rot of soybeans in Maryland. Plan Dis. Rep. 62:235-239.

23. Koning, G., Hamman, B., Eicker, A., and van de Venter, H. A. 1995. First report of Fusarium equiseti on South African soybean cultivars. Plant Dis. 79:754.

24. Leath, S., and Carroll, R. B. 1985. Use of ridge regression to predict yield reduction by Fusarium spp. in selected soybean cultivars. Can. J. Plant. Pathol. 7:58-66.

25. Leslie, J. F., Pearson, C. A., Nelson, P. E., and Toussoun, T. A. 1990. Fusarium spp. from corn, sorghum, and soybean fields in the central and eastern United States. Phytopathology 80:343-350.

26. Leslie, J. F., and Summerell, B. A. 2006. The Fusarium Laboratory Manual. Blackwell Publishing, Oxford.

27. Malvick, D. Fusarium Root rot. Minnesota Crop Diseases. University of Minnesota Extension. http://www.extension.umn.edu/cropdiseases/soybean/ fusarium.html

28. Menjivar, R. D., Hagemann, M. H., Kranz , J., Cabrera, J. A., Dababat, A. A., and Sikora, R. A. 2011. Biological control of Meloidogyne incognita on cucurbitaceous crops by the non-pathogenic endophytic fungus Fusarium oxysporum strain 162. Int. J. Pest Manage. 57:249-253.

29. Munkvold, G. P. 2003. Epidemiology of Fusarium diseases and their mycotoxins in maize ears. Eur. J. Plant Pathol. 109:705-713.

30. Munkvold, G. P., and O'Mara, J. K. 2002. Laboratory and growth chamber evaluation of fungicidal seed treatments for maize seedling blight caused by Fusarium species. Plant Dis. 86:143-150.

31. Nash, S. M., and Snyder, W. C. 1962. Quantitative estimations by plate counts of propagules of the bean root rot Fusarium in field soils. Phytopathology 52:567-572.

32. Navi, S. S., and Yang, X. B. 2008. Foliar symptom expression in association with early infection and xylem colonization by Fusarium virguliforme (formerly F. solani f. sp. glycines), the causal agent of soybean sudden death syndrome. Online. Plant Health Progress. Online publication. doi:10.1094/PHP-2008-0222-01-Rs

33. Nelson, B. D. 1999. Fusarium blight or wilt, root rot, and pod and collar rot. Pages 35-36 in: Compendium of Soybean Diseases, 3rd ed. American Phytopathological Society, St. Paul, MN.

34. Nyvall, R. F. 1976. Colonization of soybeans by species of Fusarium. Mycologia 68:1002-1010.

35. Pioli, R. N., Mozzoni, L., and Morandi, E. N. 2004. First report of pathogenic association between Fusarium graminearum and soybean. Plant Dis. 88:220.

36. Rizvi, S. S. A., and Yang, X. B. 1996. Fungi associated with soybean seedling disease in Iowa. Plant Dis. 80:57-60.

37. Rupe, J. C. 1989. Frequency and pathogenicity of Fusarium solani recovered from soybeans with sudden death syndrome. Plant Dis. 73:581584.

38. Shurtleff, M. C., and Averre, C. W., III. 1997. Glossary of Plant-Pathological Terms. American Phytopathological Society Press, St. Paul, MN.

39. Wrather, J. A. 2010. Soybean disease loss estimates for the United States, 1996-2010. Missouri Agric. Res. Sta., Delta Research Center. http:// aes.missouri.edu/delta/research/soyloss.stm

40. Wrather, J. A., Anderson, T. R., Arsyad, D. M., Gai, J., Ploper, L. D., Porta-Puglia, A., Ram, H. H., and Yorinori, J. T. 1997. Soybean disease loss estimates for the top 10 soybean producing countries in 1994. Plant Dis. $81: 107-110$.

41. Xue, A. G., Cober, E. Voldeng, H. D., Babcock, C., and Clear, R. M. 2007. Evaluation of pathogenicity of Fusarium graminearum and $\mathrm{Fu}$ sarium pseudograminearum on soybean seedlings under controlled conditions. Can. J. Plant Pathol. 29:35-40.

42. Yang, X. B., and Feng, F. 2001. Ranges and diversity of soybean fungal diseases in North America. Phytopathology 91:769-775.

43. Zhang, J. X., Xue, A. G., Zhang, H. J., Nagasawa, A. E., and Tambong, J. T. 2010. Response of soybeans cultivars to root rot caused by Fusarium species. Can. J. Plant Sci. 90:767-776. 